\title{
How different is Mediterranean Caulerpa taxifolia (Caulerpales: Chlorophyta) to other populations of the species?
}

\author{
Julie A. Phillips ${ }^{1, *}$, Ian R. Price ${ }^{2}$ \\ ${ }^{1}$ Centre for Microscopy and Microanalysis, University of Queensland, St. Lucia, Queensland 4072, Australia \\ ${ }^{2}$ Department of Biological Sciences, Monash University, Clayton, Victoria 3800, Australia
}

\begin{abstract}
The green macroalgal species Caulerpa taxifolia is indigenous to tropical/subtropical Australia, ranging as far south as $28^{\circ}$ and $29^{\circ} 15^{\prime} \mathrm{S}$ on the Australian mainland east and west coasts, respectively. The origin of disjunct populations of the species, discovered in 2000 on the Australian mainland east coast at localities to $35^{\circ} \mathrm{S}$ remains unknown, variously attributed to introduced exotic strains or range extensions from other eastern Australian populations. Some naturally occurring Australian populations of $C$. taxifolia are similar to Mediterranean C. taxifolia. In Australia, large broad forms of the species, which have been known in the region since 1860, grow luxuriantly in sheltered seagrass meadows, with some of these populations tolerating minimum surface seawater temperatures in winter of 12.5 to $14.5^{\circ} \mathrm{C}$. Accordingly, the contention that the Mediterranean has been invaded by a genetically-modified, large, cold-adapted strain of C. taxifolia may be incorrect. It is crucial that genetic markers (DNA fingerprinting, microsatellites) sensitive at the population level are used to accurately determine the genetic relatedness of $C$. taxifolia populations.
\end{abstract}

KEY WORDS: Australia · Caulerpa taxifolia · Geographic distribution · Invasive species · Seaweed · Macroalga

Resale or republication not permitted without written consent of the publisher

\section{INTRODUCTION}

The marine green macroalga Caulerpa taxifolia (Vahl) C. Agardh has gained notoriety over the last two decades as an invasive species, most notably in the Mediterranean Sea, but more recently on other continents, including Australasia (Jousson et al. 2000). Since it was first discovered in 1984 near the Musée Océanographique, Monaco (Meinesz \& Hesse 1991), C. taxifolia has spread to cover approximately 4700 ha of the Mediterranean seabed at more than 100 localities in Monaco, France, Italy, Spain and Croatia (Meinesz et al. 1998). Although the source population for the Mediterranean invasion has not been conclusively identified (Olsen et al. 1999), the presence of C. taxi-

*E-mail: j.phillips@mailbox.uq.edu.au folia in the region is currently attributed to either an aquarium escape or to a range extension by Lessepsian immigrant populations of the eastern Mediterranean. Meinesz \& Hesse (1991), Meinesz \& Boudouresque (1996) and Jousson et al. (1998) maintain that C. taxifolia, used as a decorative alga in public aquaria, was accidentally released into the sea near the Monaco Aquarium in the early 1980s. Alternatively, Chisholm et al. (1995) argued that C. taxifolia, possibly misidentified as a form of the morphologically somewhat similar Caulerpa mexicana Sonder ex Kützing, which has been present in the eastern Mediterranean as a Lessepsian immigrant from the Red Sea since the 1940s (Rayss 1941), had more recently dispersed to the western Mediterranean. The latter hypothesis has been challenged by studies of nuclear rDNA internal transcribed spacer (ITS) sequences (Olsen et al. 1998) and allozymes (Benzie et al. 2000), which have demon- 
strated that C. taxifolia and C. mexicana are separate entities. However, it remains possible that some populations of $C$. mexicana recorded from the Mediterranean, which were not investigated in above molecular studies, could be the misidentified C. taxifolia referred to by Chisholm et al. (1995) and Chisholm \& Jaubert (1999).

Although Caulerpa taxifolia is reported to be widely distributed in the tropical Atlantic (Taylor 1960, Wynne 1986, 1998, Lawson \& John 1987), Indian (Silva et al. 1996) and Pacific Oceans (Harvey 1860, Cribb 1958, Silva et al. 1987), the geographical range of the species in Australia has not previously been comprehensively documented in the literature. C. taxifolia has been reported from the eastern Australian coast (Harvey 1860, Lucas 1931, Cribb 1958, Price et al. 1976, Ngan \& Price 1979, 1980a,b, Saenger 1979, Cribb 1996) and offshore in the South Pacific Ocean at Lord Howe
Island, New South Wales (NSW) (Lucas 1935, Millar \& Kraft 1994). Unfortunately, these records, some published decades ago in specialist phycological literature, are often overlooked. There is no comprehensive flora for Australian tropical macroalgae which would provide readily accessible distributional data for the species in Australia. It is therefore not surprising that comparisons of the similarities between Mediterranean and Moreton Bay populations of C. taxifolia (Pillen et al. 1998, Benzie et al. 2000) fuelled speculation of a recent introduction of the species into subtropical eastern Australia. Recent discoveries of disjunct populations of C. taxifolia on the NSW mainland coast, up to $800 \mathrm{~km}$ south of the species' southern distribution limit on the Australian continent, renewed the introduction debate and highlighted the need for detailed knowledge of the species in Australia for the purposes of developing management strategies for this potentially

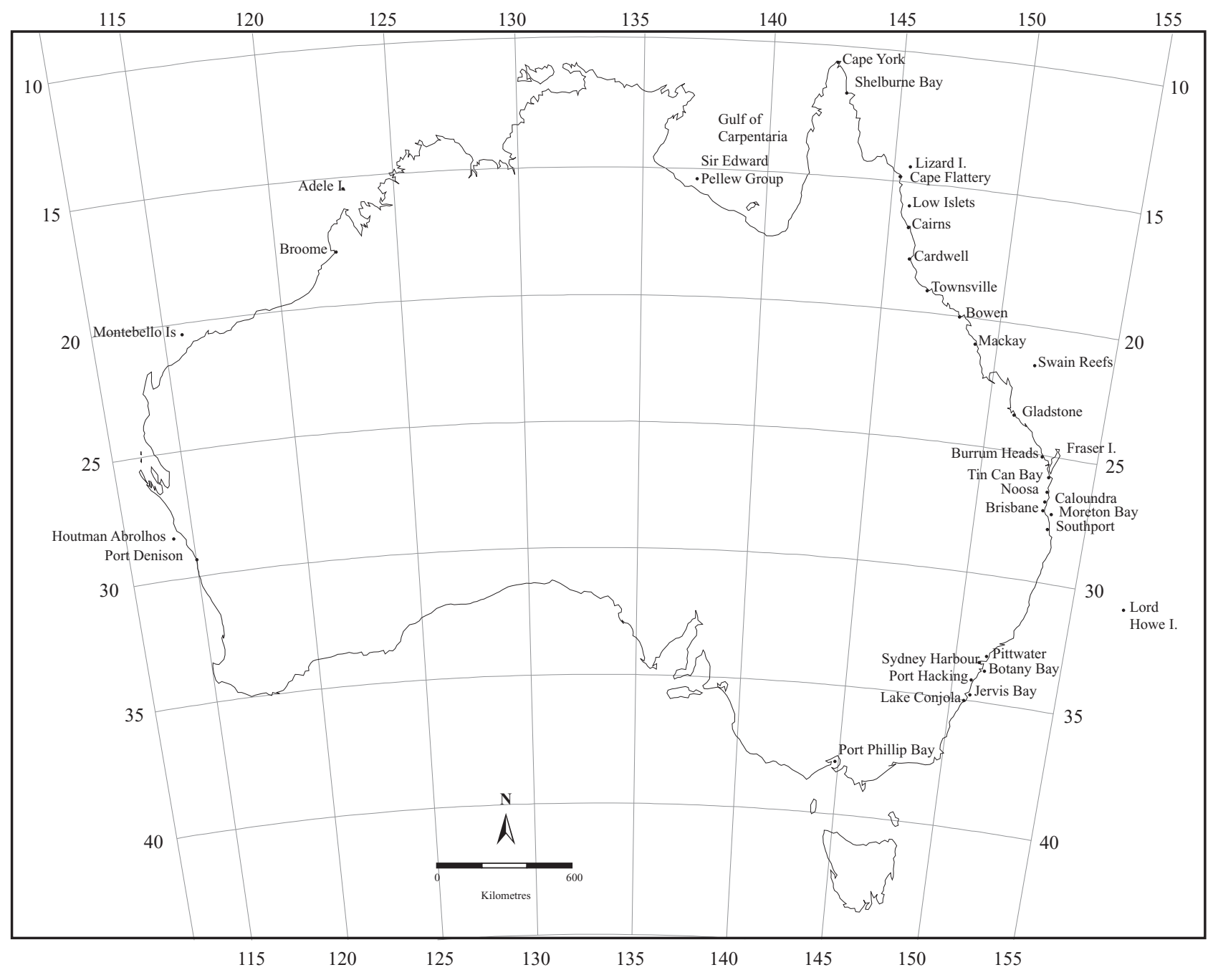

Fig 1. Caulerpa taxifolia. Geographic distribution in Australia 
invasive alga. Despite the lack of published information, many specimens of Australian C. taxifolia are housed in Australian and European herbaria and many recent collections have been documented by one of us (I.R.P.) during a revision of the Australian representatives of the genus. This paper aims to clearly establish that C. taxifolia is indigenous to tropical/subtropical Australia, to document the geographical range of the species in Australia based on collections since 1855, to confirm determinations of herbarium specimens, to discuss intraspecific morphological variation and to provide an accurate scientific basis for further research on and management of the species in Australia. Furthermore, data on naturally occurring Australian and other tropical/subtropical populations of C. taxifolia may be useful in managing invasions of the species elsewhere, particularly in determining whether Mediterranean populations are markedly different to other populations of the species.

\section{METHODS}

Collections of Caulerpa taxifolia housed in most Australian and major European herbaria, as well as recent field collections and observations by various workers (including I.R.P.) were studied in order to confirm specimen identifications, to describe the morphological variability exhibited by the species and to fully document the geographical distribution of the species in Australia. Herbarium collections of $C$. taxifolia from Australia have been accrued over many decades, the result mostly of opportunistic collecting, less often from planned systematic ecological surveys or monitoring programs. In order to describe some of the important morphological variability of C. taxifolia in Australia, frond height and breadth measurements were recorded from herbarium specimens.

\section{RESULTS AND DISCUSSION}

Caulerpa taxifolia is indigenous to tropical/subtropical Australia, evident from the many collections in the region (Figs. 1 \& 2, Table 1), particularly those from the widely disparate localities of Cape York, Cardwell, Bowen and Caloundra on the eastern Australian coast, made 80 to $145 \mathrm{yr}$ ago at the time of some of the earliest algal collections in subtropical/tropical Australia. This natural occurrence is also consistent with the observations that macroalgal species are generally not good dispersers across ocean basins (van den Hoek 1987) and that the biology of C. taxifolia hinders transoceanic, human-meditated dispersal of the species. C. taxifolia is not a fouling organism of ship hulls,

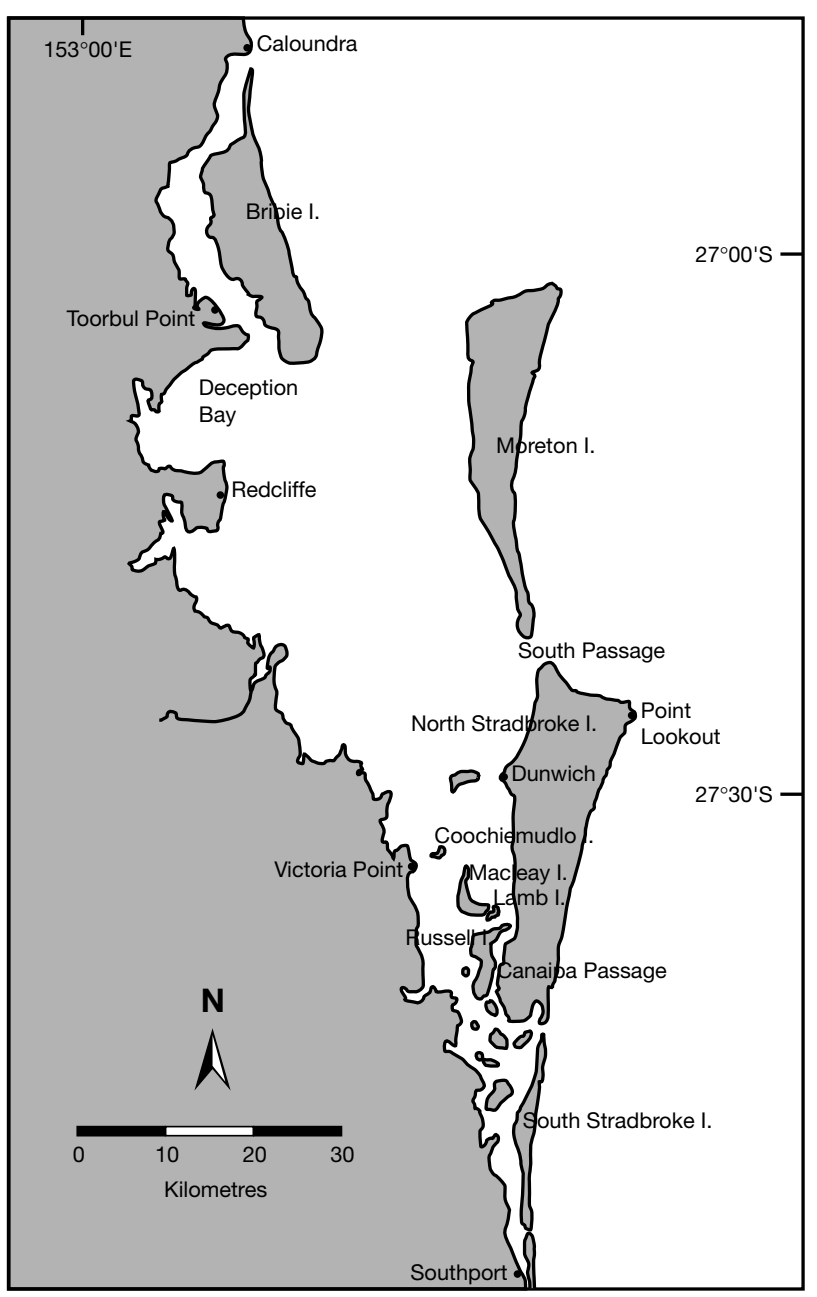

Fig. 2. Caulerpa taxifolia. Distribution of in subtropical Moreton Bay on the eastern Australian coast

a common method for the global transport of some exotic marine macroalgal species since the 19th century (Adams 1983, Nelson 1999), and there is little evidence to establish whether or not mature thalli, gametes, zygotes or the microscopic diploid stage would be viable after deballasting by ships following extended periods of darkness in ballast tanks. There is also no evidence for the accidental introduction of $C$. taxifolia when transporting invertebrate species to foreign mariculture facilities, a practise which has introduced many exotic macroalgal species to other continents since the early 1900s (Ribera \& Boudouresque 1995). Rather, transport of living thalli by the aquarium trade seems to be the most probable method of dispersal, consistent with the first observation of $C$. taxifolia in the Mediterranean near the aquarium at Monaco in the early 1980s (Meinesz \& Hesse 1991, Meinesz \& Boudouresque 1996, Jousson et al. 1998). 


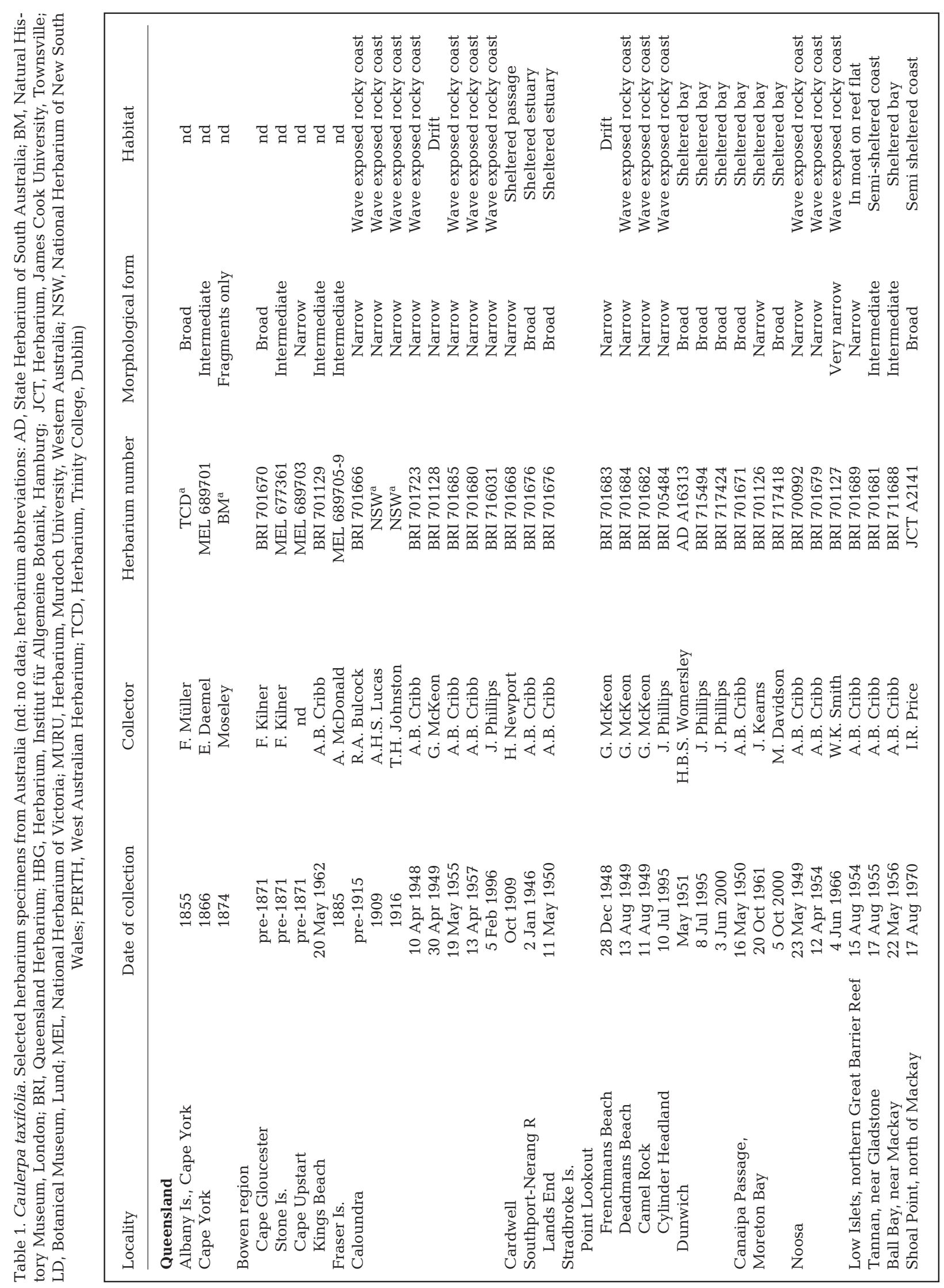




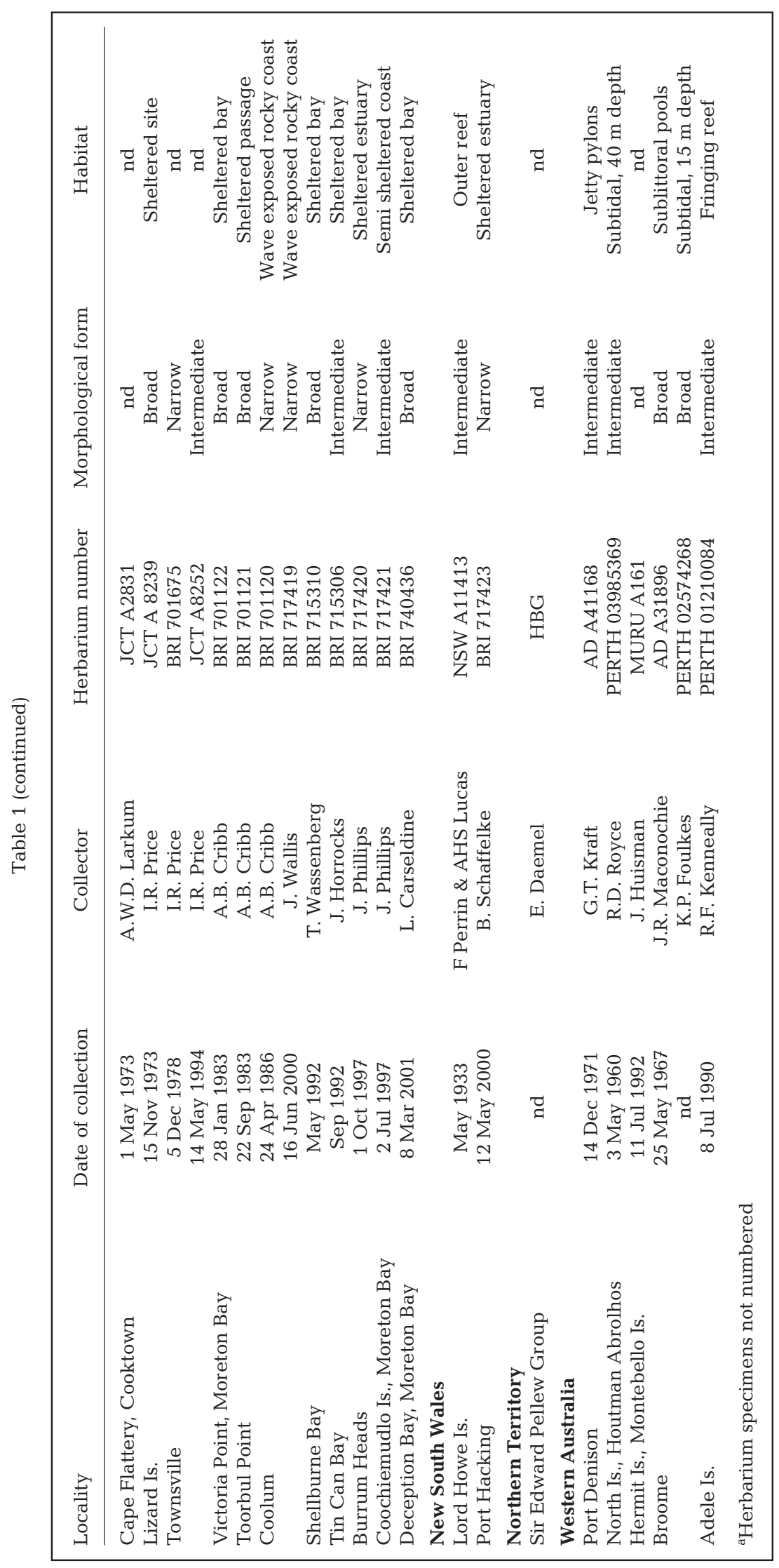

This initial localised occurrence of $C$. taxifolia in the Mediterranean, followed by the relatively rapid spread by shortdistance transport of thallus fragments entangled in boating gear and fishing nets (Meinesz 1992, Sant et al. 1996, Ceccherelli \& Cinelli 1999, Smith \& Walters 1999), fits the scenario of an invasion, contrasting markedly to the wide distribution pattern for Australian C. taxifolia documented over almost 150 yr. Although it is clear that indigenous populations of $C$. taxifolia are widespread in Australia, reports of similarities between some Australian and Mediterranean populations raise the possibility of recent introductions of exotic strains into Australia.

Caulerpa taxifolia is a common species in tropical/subtropical eastern Australia, occurring along the mainland coast, on the Great Barrier Reef (GBR) and on offshore islands, from Cape York $\left(11^{\circ} 54^{\prime} \mathrm{S}, 142^{\circ} 15^{\prime} \mathrm{E}\right)$ to Southport $\left(28^{\circ} 00^{\prime} \mathrm{S}, 153^{\circ} 20^{\prime} \mathrm{E}\right)$. The many collections of $C$. taxifolia made in Queensland during the late 19th and early 20th centuries, a period when the state was sparsely populated and when algal collections were usually made by foreign or amateur collectors, indicate that the species was relatively common at that time. Harvey (1860, Plate 178) was first to publish the occurrence of C. taxifolia for Australia, the record based on specimens collected at Albany Island, near Cape York in August, 1855 by the Victorian Government botanist Baron F. von Müller, during his participation on A. C. Gregory's North Australia Expedition (1855 to 1856) (Gregory 1884). Sonder $(1871,1881)$ and Lucas (1931) also cite specimens sampled by the plant collectors E. Daemel and F. Kilner from Cape York and the Bowen region, respectively, and early unpublished herbarium records locate the species at Cardwell in the tropics, at Fraser Island in the subtropics and even further south at Caloundra on the northern boundary of Moreton Bay (Figs. 1 \& 2, Table 1). The Caloundra collections were made by A. H.S. Lucas, the first resident Australian phycologist in 1909 during an expedition 
from Sydney and by the naturalist R. A. Bulcock. The label on the undated Bulcock specimen sheet was written by F. M. Bailey, the Colonist Botanist of Queensland (A. Bolin, Queensland Herbarium, pers. comm.), evidently before Bailey's death in 1915. Since the late 1940s, phycologists resident in Queensland have reported C. taxifolia from Noosa and Moreton Bay (Cribb 1958), Swain Reefs (southern GBR) (Saenger 1979), the Townsville region (Ngan \& Price 1979, 1980a,b) and Lizard Island (northern GBR) (Price et al. 1976); these published records represent only a small proportion of the Queensland collections lodged in herbaria (Table 1). Many Queensland collections, including the 1951 collection from the Dunwich population that has been considered similar to Mediterranean populations (Pillen et al. 1998, Benzie et al. 2000, Chisholm et al. 2000), were made well before $C$. taxifolia was reported to be an invasive species in the Mediterranean.

In contrast to the Queensland coast, records of Caulerpa taxifolia from the tropical northern and western Australian coasts are limited to 1 published record from the Montebello Islands, Western Australia (WA) (Huisman 2000). Herbarium collections document the geographical range of C. taxifolia on the western Australian coast further south to Port Denison $\left(29^{\circ} 15^{\prime} \mathrm{S}\right.$, $114^{\circ} 56^{\prime} \mathrm{E}$ ), and provide 3 more records for WA and the only record, from the Sir Edward Pellew group $\left(15^{\circ} 33^{\prime} \mathrm{S}, 114^{\circ} 04^{\prime} \mathrm{E}\right)$ in the southwestern Gulf of Carpentaria, for the Northern Territory (Fig. 1, Table 1). This apparent rare occurrence of the species on northern and western Australian coasts very likely reflects the paucity of algal collections in these remote regions, which still remain relatively thinly settled and poorly studied scientifically. Prior to a recent publication which reported some macroalgal collections from tropical WA (Huisman 2000), only 28 marine macroalgal species had been recorded from this coastline, which is several thousand kilometres in length and for which records of at least 300 species could be expected (Huisman et al. 1998). The wide distribution of C. taxifolia in tropical seas (Harvey 1860, Weber-van Bosse 1913, Silva et al. 1996), including in regions to Australia's immediate north such as Indonesia (Weber van Bosse 1898, 1913, Coppejans \& Prud'Homme van Reine 1992), also suggests that C. taxifolia is probably more widespread on tropical northern and western Australian coasts than collections for the region presently indicate.

The discovery in 2000 of disjunct populations of Caulerpa taxifolia in the Pittwater $\left(33^{\circ} 38^{\prime} \mathrm{S}, 151^{\circ} 18^{\prime} \mathrm{E}\right)$, in Port Hacking $\left(34^{\circ} 06^{\prime} \mathrm{S}, 151^{\circ} 10^{\prime} \mathrm{E}\right)$ and in Lake Conjola $\left(35^{\circ} 16^{\prime} \mathrm{S}, 150^{\circ} 30^{\prime} \mathrm{S}\right)$ on the central mainland coast of NSW, locates the species up to $800 \mathrm{~km}$ further south than its previous southern distributional limit on the Australian mainland east coast, at Southport $\left(28^{\circ} 00^{\prime} \mathrm{S}, 153^{\circ} 20^{\prime} \mathrm{E}\right)$ and thus represents a significant range extension for $C$. taxifolia on the Australian mainland east coast. It is unlikely that $C$. taxifolia had been overlooked on the NSW coast, which has been relatively well studied phycologically since the early 1900s, particularly since southern outlier populations of the species had been previously reported from the oceanic Lord Howe Island (31 $33^{\circ} \mathrm{S}, 159^{\circ} 05^{\prime} \mathrm{E}$ ) (Lucas 1935, Millar \& Kraft 1994), which is remote from, but politically part of NSW. Lord Howe Island is more strongly influenced by the warm East Australian Current than the mainland coast, which results in warmer (17 to $25^{\circ} \mathrm{C}$ annually) surface seawater temperatures (SSTs) (Allen \& Paxton 1974) than would normally be experienced at such a high latitude, including the warm temperate mainland coast of NSW (see Womersley 1984), where the new populations of C. taxifolia have been discovered. Lord Howe Island is regarded as a tropical outpost in the South Pacific Ocean, supporting probably the world's southernmost coral reef (Allen \& Paxton 1974), many tropical macroalgal species (Millar \& Kraft 1994) and hermatypic corals (Harriott et al. 1995).

The occurrence of Caulerpa taxifolia at regular intervals along the eastern Australian coast from tropical Cape York to subtropical Southport and also as far south as subtropical Port Denison on the western Australian coast indicates that it is not a strictly tropical species as has often been stated (Meinesz \& Boudouresque 1996, Komatsu et al. 1997, Jousson et al. 2000), but rather belongs to a large group of macroalgal species that have a tropical to warm temperate distribution pattern. C. taxifolia has previously been reported from warm temperate Bermuda $\left(32^{\circ} \mathrm{N}\right)$ (Taylor 1960) and the Gulf of Suez ( 28 to $30^{\circ} \mathrm{N}$ ) (Chisholm et al. 2000). Furthermore, the genus Caulerpa is not a strictly tropical genus, with 8 of the 12 species (forms and varieties not considered) recorded for Queensland, ranging from the tropics to subtropical Moreton Bay (Phillips 1997). Three of these species (Caulerpa brachypus Harvey, C. lentillifera J. Agardh and C. peltata Lamouroux) have a similar distribution in the Indian Ocean, where they range as far south as South Africa (Silva et al. 1996).

Strictly tropical macroalgal species are stenothermal, having a lower temperature tolerance limit of 18 to $20^{\circ} \mathrm{C}$, which corresponds to the $20^{\circ} \mathrm{C}$ winter seawater isotherm (Pakker et al. 1995, 1996). This isotherm occurs on the Australian east coast near $23^{\circ} \mathrm{S}$ latitude (Middleton 1995), approximately $550 \mathrm{~km}$ north of Southport, the pre-2000 southern distribution limit of Caulerpa taxifolia on this coast. On the Australian west coast, the $20^{\circ} \mathrm{C}$ winter seawater isotherm appears on SST maps (see Middleton 1995) to be located at $29^{\circ} \mathrm{S}$, 
but this reflects the warming effect of the offshore winter southward-flowing Leeuwin Current, a phenomenon also responsible for the higher SSTs offshore Houtman Abrolhos $\left(28^{\circ} 43^{\prime} \mathrm{S}\right)$. Inshore waters at the same latitude, which are not influenced by this current, have SSTs 4 to $7^{\circ} \mathrm{C}$ lower (Dakin 1919), and consequently the extent of truly tropical waters inshore is even further north, at $22^{\circ} \mathrm{S}$ (Morgan \& Wells 1991). Macroalgal species with tropical to warm temperate distribution patterns have a lower temperature tolerance limit of 10 to $15^{\circ} \mathrm{C}$ (Cambridge et al. 1987, 1990a,b, Breeman 1988, Lüning 1990, Pakker et al. 1996), and these temperature limits correlate well with the distributional limits of C. taxifolia in the Moreton Bay region on the east coast and Port Denison on the west coast. Moreton Bay experiences an annual SST variation of 14.5 to $27.5^{\circ} \mathrm{C}$ (Endean et al. 1956), although a greater annual $\mathrm{SST}$ variation $\left(12.5\right.$ to $\left.32^{\circ} \mathrm{C}\right)$ was reported during a coral study in shallow eastern bay waters (Johnson \& Neil 1998) where C. taxifolia is common (J. Phillips pers. obs). Winter minimum SSTs in Moreton Bay are similar to winter temperatures reported for the Mediterranean Sea, and these temperatures are also consistent with the lower lethal temperature limit of 10 to $13^{\circ} \mathrm{C}$ for Mediterranean C. taxifolia (Meinesz \& Hesse 1991, Komatsu et al. 1997) and of 9 to $11^{\circ} \mathrm{C}$ for C. taxifolia from Moreton Bay (Chisholm et al. 2000). These observations further support the challenge by Chisholm et al. (2000) contesting the assertion that Mediterranean populations of $C$. taxifolia are composed of genetically modified, cold-adapted strains (Meinesz \& Hesse 1991, Komatsu et al. 1997, Jousson et al. 2000).

The mainly sporadic collecting of macroalgae along much of the tropical/subtropical Australian coast has resulted in the limited published data on the abundance of Caulerpa taxifolia in tropical/subtropical Australia. In tropical northern Queensland, C. taxifolia is locally abundant in winter and spring, usually occurring in the lower intertidal zone on waveexposed rocky shores along the mainland coast in the Townsville region as well as on hard substrata on reef flats of the GBR (Ngan \& Price 1980a,b, I. R. Price pers. obs.). In southern Queensland, at the wave exposed localities of Coolum, Caloundra and Point Lookout, C. taxifolia is not common, growing in the sublittoral fringe and subtidally attached to rocks covered by an algal turf (J. Phillips pers. obs.). The abundance of $C$. taxifolia in sheltered Moreton Bay is variable, the species appearing to be more abundant in the eastern bay, where it has been noted during seagrass surveys. On Macleay, Lamb and Russell Islands, C. taxifolia forms a monospecific narrow band, slightly deeper than the adjacent intertidal Zostera/ Halophila seagrass community (FRC Coastal Resource and Environmental 1996). On channel edges near Moreton Island, on the Aldershot Banks, off South Stradbroke Island (as Caulerpa mexicana, Young \& Kirkman 1975) and at Dunwich, North Stradbroke Island (Pillen et al. 1998), the species grows subtidally with the seagrass Halophila spinulosa (R. Br.) Aschers. The density of the erect fronds of C. taxifolia in dense stands at Dunwich is slightly less at $4183 \pm$ 1370 fronds $\mathrm{m}^{-2}$ (Pillen et al. 1998), than the density (5100 to 13920 primary fronds $\mathrm{m}^{-2}$ ) reported for Mediterranean populations of the species (Meinesz et al. 1995).

Thalli of the western Mediterranean Caulerpa taxifolia have been considered to be much larger than those of tropical strains of the species (Meinesz \& Hesse 1991, Meinesz et al. 1995). However, large broad forms of this morphologically variable species are not of recent origin, having long ago been reported by Harvey (1860) from Albany Island, Australia, and from abundant collections in Ceylon (Sri Lanka) and the Friendly Islands (Tonga). Fronds of the Albany Island specimens reported by Harvey are 13 to $14.5 \mathrm{~cm}$ long and 1.7 to $2 \mathrm{~cm}$ broad. Sonder (1871) reported specimens from Cape York, Albany Island and Bowen as C. taxifolia var. asplenioides Harvey, the 'var. asplenioides' used during the 19th century to denote the broad form of the species. Børgesen (1907) reported erect fronds of C. taxifolia from St Jan, West Indies, growing at $30 \mathrm{~m}$ depth to be ' $16 \mathrm{~cm}$ or more' long and $1.5 \mathrm{~cm}$ broad.

The broad form of Caulerpa taxifolia is found at many localities in Queensland (Table 1) and is only 1 morphotype expressed by the species in this geographical region. Although there is some variation within any given population, broad forms of C. taxifolia generally occur on unconsolidated substrates in sheltered bays and estuaries along the whole coastline, intermediate forms occur in habitats exposed to moderate wave action, as on the mainland coast bordering the GBR lagoon, and narrow forms inhabit the shallow sublittoral zone on wave-exposed coasts in southern Queensland and on the outer reef edges in the GBR system. Harvey (1860), Børgesen (1907) and Cribb (1958) also described similar correlation between thallus size and habitat for C. taxifolia from Tonga, West Indies, and southern Queensland, respectively. Although various different morphological forms of $C$. taxifolia (e.g. narrow and broad) can be recognised, variation in frond size is continuous, grading from one form to another. Australian specimens of C. taxifolia we examined varied from 1.5 to $20 \mathrm{~cm}$ in frond length and from 2 to $20 \mathrm{~mm}$ in frond breadth, although Cribb (1996) reported frond lengths up to $30 \mathrm{~cm}$ for broad forms growing in Moreton Bay. Generally, narrow Australian forms have fronds 2 to $10 \mathrm{~cm}$ long and 2 to 
$5 \mathrm{~mm}$ broad, fronds of intermediate forms are 2 to $10 \mathrm{~cm}$ long and 6 to $9 \mathrm{~mm}$ broad and fronds of broad forms are 5 to $20 \mathrm{~cm}$ long and 10 to $20 \mathrm{~mm}$ broad. Tropical Queensland specimens tended to be typically smaller than southern Queensland plants, usually attaining a maximum length and breadth of $15 \mathrm{~cm}$ and $15 \mathrm{~mm}$, respectively.

The recent discovery of Caulerpa taxifolia in New South Wales, well outside of the documented pre-2000 geographical range of the species in Australia, caused considerable concern among phycologists and government departments responsible for managing the marine environment. Although it is now evident that C. taxifolia is indigenous to tropical/subtropical Australia, it has not yet been possible to determine whether the populations from mainland NSW represent an introduction from outside Australia, possibly released into the wild by aquarium hobbyists, or a significant range extension sourced from Queensland populations either via intermittent incursions inshore of East Australian Current waters or by humanmediated dispersal. Distinguishing between indigenous and exotic populations of the same species is difficult. In such circumstances, proof of an introduction of exotic populations of $C$. taxifolia cannot be based solely on large or increasing population size since Caulerpa species are known to exhibit marked fluctuations in population size, both in the Mediterranean (C. prolifera [Forskål] Lamouroux and C. racemosa [Forskål] J. Agardh; Meinesz et al. 1995, Chisholm \& Jaubert 1999 and references therein) and in Australia.

There is ample evidence that several of the more than 20 species of Caulerpa recorded for Australia can be locally abundant, particularly in bays and estuaries close to large population centres. The southern Australian endemic species, C. remotifolia Sonder and $C$. longifolia C. Agardh, which are common at many localities in the Port Phillip Bay, Victoria (King et al. 1971), were, together with the cosmopolitan Ulva lactuca L., community dominants in the upper subtidal zone near the then major sewage outfall for Melbourne at Werribee (Axelrad et al. 1981). Unlike many other algal species, such as the kelp Ecklonia radiata (C. Agardh) J. Agardh, C. remotifolia and C. longifolia did not disappear from, but flourished in habitats near the outfall. The Indian Ocean C. scalpelliformis (R. Brown ex Turner) C. Agardh, which in Australia ranged from Perth on the western Australian coast along the south coast to Jervis Bay on the Australian east coast (Womersley 1984), has recently extended its geographical range by approximately $150 \mathrm{~km}$ to become locally abundant in Botany Bay (Davis et al. 1997). C. filiformis (Suhr) Hering, which was first reported for Australia in 1927 from a single locality in Botany Bay and as drift in Sydney Harbour (Lucas
1927, as C. ligulata Harvey), had originally been described from South Africa almost a century earlier (Suhr 1834). Subsequently, May (1976) reported the species as locally dominant at numerous other locations in the Sydney region and attributed the increase in abundance to either acclimation and spread of an introduced species or to an increasing volume of sewage discharged in the area over the previous 20 years. The likelihood of the former hypothesis appeared to be diminished by a study of nuclear ITS sequences, which demonstrated that Australian and African populations of $C$. filiformis were sufficiently different to be regarded as 2 distinct species (Pillmann et al. 1997). However, the introduction hypothesis cannot be totally discounted, because the few African populations of $C$. filiformis sampled may not have included the source population of any putative introduction (Dr G. Zuccarello pers. comm.). A dense population of C. taxifolia at Dunwich, Moreton Bay, has been reported as expanding (Pillen et al. 1998), but as no prior quantitative data exist and the population apparently was only sampled once, the claimed increase in population size cannot be substantiated, particularly since dense populations of $C$. taxifolia were observed during seagrass surveys in eastern Moreton Bay 3 decades ago (Young \& Kirkman 1975).

Molecular genetics may provide the means to determine whether exotic populations of Caulerpa taxifolia occur in Australia, and if they coexist and can hybridise with Australian indigenous populations of the species. Molecular genetic markers such as allozymes (Benzie et al. 1997) and sequences of the rDNA ITS region (Pillmann et al. 1997, Olsen et al. 1998) have been used successfully to distinguish different species of Caulerpa, but these markers lack the resolution necessary to differentiate populations of a species, providing only inconclusive results when applied to population level studies of C. taxifolia (Jousson et al. 1998, 2000, Benzie et al. 2000). Macroalgal species generally have low levels of electrophoretically detectable genetic variation at the population level (Sosa \& Lindstrom 1999), a feature which also applies to C. taxifolia (Benzie et al. 1997, 2000). Limited intraspecific variability of the rDNA ITS region has normally been detected using DNA sequence information, indicating that this type of information is inadequate for determining population structure and for distinguishing different C. taxifolia populations (Hillis et al. 1996, Olsen et al. 1998, 1999).

Developing management protocols for Australian Caulerpa taxifolia relies on establishing if exotic strains have been introduced and then differentiating indigenous from exotic populations of the species. No systematic studies have been undertaken to determine the population structure of $C$. taxifolia anywhere in the world, although these data are an essential prerequi- 
site before conclusive statements can be made about migration and introduction of $C$. taxifolia strains outside their natural geographical range. High-resolution genetic markers (DNA fingerprints, microsatellites), which would enable detailed analysis of polymorphism in macroalgae at the intraspecific level, have not as yet been applied to $C$. taxifolia populations, even though these techniques have been used on populations of other macroalgal species. The use of such molecular genetic markers becomes especially powerful in combination with a well thought-out and rigorous fieldsampling program of various populations aimed at describing the full extent of genotypic diversity in a species, vital information that previous molecular studies on $C$. taxifolia have failed to establish. It is only after these criteria have been incorporated into molecular studies that possible relationships between eastern Australian and Mediterranean populations (Pillen et al. 1998, Benzie et al. 2000, Jousson et al. 2000) can be conclusively evaluated.

The present paper clearly demonstrates the need to undertake studies on naturally occurring populations of invasive species, in order to gain an accurate perspective on the biology of the species. We have shown that Mediterranean populations of Caulerpa taxifolia are not markedly different to some Australian tropi$\mathrm{cal} /$ subtropical populations of the species. Natural populations of $C$. taxifolia generally exhibit considerable size variation, including a broad form which has been reported from tropical oceans for nearly $150 \mathrm{yr}$ and which is comparable in its morphology to the Mediterranean form. From its geographic distribution on Australian coasts, it is obvious that $C$. taxifolia is not a strictly tropical species, but ranges south into the subtropics, the southernmost populations experiencing similar SSTs to those in the Mediterranean Sea. Furthermore, the broad form of C. taxifolia is abundant in seagrass meadows in Moreton Bay, similar to the niche that the invasive alga now occupies in the Mediterranean. In view of these findings and in the absence of definitive population-level genetic studies, there is still insufficient evidence to support the assertion that the Mediterranean is being invaded by an exceptionally vigorous, cold-tolerant, genetically modified strain of C. taxifolia (Komatsu et al. 1997, Jousson et al. 1998, 2000).

Acknowledgements. We thank Duncan Waddell (CMM) for preparing the maps, Carol Conacher (FRC Coastal Resource and Environmental) for valuable discussions of $C$. taxifolia from Moreton Bay and the following Institutions: State Herbarium, South Australia; Natural History Museum, London; Queensland Herbarium; Herbarium, Institut für Allgemeine Botanik, Hamburg; Herbarium, James Cook University; Botanical Museum, Lund; National Herbarium of
Victoria; Herbarium, Murdoch University; National Herbarium of New South Wales; Western Australian Herbarium; Herbarium, Trinity College, Dublin; for providing access to and helpful information about their collections.

\section{LITERATURE CITED}

Adams NM (1983) Checklist of marine algae possibly naturalised in New Zealand. NZ J Bot 21:1-2

Allen GR, Paxton JR (1974) A tropical outpost in the South Pacific. Aust Nat Hist 18:50-55

Axelrad DM, Poore GCB, Arnott GH, Bauld J and 3 others (1981) The effects of treated sewage discharge on the biota of Port Phillip Bay, Victoria, Australia. In: Nielsen BJ, Cronin LE (eds) Estuaries and nutrients. Humana Press, Clifton, NJ, p 279-305

Benzie JAH, Price IRP, Ballment E (1997) Population genetics and taxonomy of Caulerpa (Chlorophyta) from the Great Barrier Reef, Australia. J Phycol 33:491-504

Benzie JAH, Ballment E, Chisholm JRM, Jaubert JM (2000) Genetic variation in the green alga Caulerpa taxifolia. Aquat Bot 66:131-139

Børgesen F (1907) An ecological and systematic account of the Caulerpas of the Danish West Indies. Kgl Dan Vidensk, Selsk Biol Skr 7:340-391

Breeman AM (1988) Relative importance of temperature and other factors in determining geographic boundaries of seaweeds: experimental and phenological evidence. Helgol Wiss Meeresunters 42:199-241

Cambridge ML, Breeman AM, Kraak S, van den Hoek C (1987) Temperature responses of tropical to warm temperate Cladophora species in relation to their distribution in the North Atlantic Ocean. Helgol Wiss Meeresunters 41:329-354

Cambridge ML, Breeman AM, van den Hoek C (1990a) Temperature limits at the distributional boundaries of four tropical to temperate species of Cladophora species in the North Atlantic Ocean. Aquat Bot 38:135-151

Cambridge ML, Breeman AM, van den Hoek C (1990b) Temperature limits at the distributional boundaries of European and American warm temperate Cladophora species (Cladophorales, Chlorophyta) in the North Atlantic. Bot Mar 33:355-362

Ceccherelli G, Cinelli F (1999) The role of vegetative fragmentation in dispersal of the invasive alga Caulerpa taxifolia in the Mediterranean. Mar Ecol Prog Ser 182: 299-303

Chisholm JRM, Jaubert JM (1999) Comments on the article of Olsen et al (1998): Mediterranean Caulerpa taxifolia and Caulerpa mexicana (Chlorophyta) are not conspecific. J Phycol 35:438-440

Chisholm JRM, Jaubert JM, Giaccone G (1995) Caulerpa taxifolia in the northwest Mediterranean: introduced species or migrant from the Red Sea? C R Acad Sci Ser III Sci Vie 318:1219-1226

Chisholm JRM, Marchioretti M, Jaubert JM (2000) Effect of low water temperature on metabolism and growth of a subtropical strain of Caulerpa taxifolia (Chlorophyta). Mar Ecol Prog Ser 201:189-198

Coppejans E, Prud'Homme van Reine WF (1992) Seaweeds of the Snellius-II expedition (E. Indonesia): the genus Caulerpa (Chlorophyta-Caulerpales). Bull Séanc Acad R Sci Outre-Mer 37:667-712

Cribb AB (1958) Records of marine algae from south-eastern Queensland. IV. Caulerpa. Univ Qld Pap Dept Bot 3: 209-220 
Cribb AB (1996) Seaweeds of Queensland. A naturalist's guide. Queensland Naturalists Club, Brisbane

Dakin WJ (1919) The Percy Slade Trust Expedition to the Abrolhos Is. J Linn Soc Zool 34:127-180

Davis AR, Roberts DE, Cummins SP (1997) Rapid invasion of a sponge-dominated deep-reef by Caulerpa scalpelliformis (Chlorophyta) in Botany Bay, New South Wales. Aust J Ecol 22:146-150

Endean R, Kenny R, Stephenson W (1956) The ecology and distribution of intertidal organisms on the rocky shores of the Queensland mainland. Aust J Mar Freshw Res 7: 88-146

FRC Coastal Resource and Environmental (1996) Environmental investigations and ecological capacity of the islands: intertidal and subtidal flora and fauna. In: Southern Bay Islands planning and land use strategy. GHD Environmental Consultants, Brisbane

Gregory AC (1884) North Australia Expedition. In: Gregory AC, Gregory FT (eds) Journals of the Australian Explorations 1846-1858. Government Printer, Brisbane, p 99-194

Harriott V, Harrison PL, Banks, SA (1995) The coral communities of Lord Howe Island. Mar Freshw Res 46:457-465

Harvey WH (1860) Phycologia Australica. Vol 3. Reeve, London

Hillis DM, Moritz C, Mable BK (1996) Molecular systematics. Sinauer Associates, Sunderland, MA

Huisman JM (2000) Marine Plants of Australia. University of Western Australia Press, Perth

Huisman JM, Cowan RA, Entwisle TJ (1998) Biodiversity of Australian marine macroalgae. A progress report. Bot Mar 41:89-93

Johnson PR, Neil DT (1998) The corals of Moreton Bay: living with extremes. In: Tibbetts IR, Hall NJ, Dennison WC (eds) Moreton Bay and catchment. School of Marine Science, University of Queensland, Brisbane, p 503-524

Jousson O, Pawlowski J, Zaninetti L, Meinesz A, Boudouresque CF (1998) Molecular evidence for the aquarium origin of the green alga Caulerpa taxifolia introduced into the Mediterranean Sea. Mar Ecol Prog Ser 172:275-280

Jousson O, Pawlowski J, Zaninetti L, Zechman FW and 5 others (2000) Invasive alga reaches California. Nature 408: $157-158$

King RJ, Black JH, Ducker SC (1971) Intertidal ecology of Port Phillips Bay with systematic list of plants and animals. Mem Natl Mus Vic 31:93-128

Komatsu T, Meinesz A, Buckles D (1997) Temperature and light responses of the alga Caulerpa taxifolia introduced into the Mediterranean Sea. Mar Ecol Prog Ser 146:145-153

Lawson GW, John DM (1987) The marine algae and coastal environment of tropical West Africa. Beih Nova Hedwigia 93

Lucas AHS (1927) Notes on Australian marine algae. V. Proc Linn Soc NSW 52:555-562

Lucas AHS (1931) The marine algae hitherto recorded from north-eastern Australia. Rep Gt Barrier Reef Commi 3: $47-57$

Lucas AHS (1935) Marine algae of Lord Howe Island. Proc Linn Soc NSW 60:194-232

Lüning K (1990) Seaweeds. Their environment, biogeography and ecophysiology. John Wiley \& Sons, New York

May V (1976) Changing dominance of an algal species (Caulerpa filiformis [Suhr] Hering). Telopea 1:136-138

Meinesz A (1992) Modes de dissémination de l'algue Caulerpa taxifolia introduite en Méditerranée. Rapp P-V Réun Commn Int Explor Scient Mer Méditerr 33B:44
Meinesz A, Boudouresque CF (1996) Sur l'origine de Caulerpa taxifolia en Méditerranée. C R Acad Sci Ser III Sci Vie 319:603-613

Meinesz A, Hesse B (1991) Introduction et invasion de l'algue tropicale Caulerpa taxifolia en Méditerranée nord-occidentale. Oceanol Acta 14:415-426

Meinesz A, Benichou L, Blachier J, Komatsu T, Lemee R, Molenaar H, Mari X (1995) Variations in the structure, morphology and biomass of Caulerpa taxifolia in the Mediterranean Sea. Bot Mar 38:499-508

Meinesz A, Cottalorda JM, Chiaverini D, Cassar N and 14 others (1998) Bilan et analyse de la situation de l'expansion de Caulerpa taxifolia en Méditerranée a la fin de 1997. In: Meinesz A, Cottalorda JM, Chiavérni D, Cassar N, de Vaugelas J (eds) Suivi de l'invasion de l'algue tropicale Caulerpa taxifolia en Méditerranée: situation au 31 Decémbre 1997. LEMI Université de Nice-Sophia Antipolis Publications, Nice, p 7-24

Middleton JH (1995) The oceanography of Australian seas. In: Zann LPG, Kailola P (eds) State of the marine environment report. Technical Annex 1, Great Barrier Reef Marine Park Authority, Townsville, Australia, p 1-10

Millar AJK, Kraft GT (1994) Catalogue of marine benthic green algae (Chlorophyta) of New South Wales, including Lord Howe Island, south-western Pacific. Aust Syst Bot 7: 419-453

Morgan GJ, Wells FE (1991) Zoogeographic provinces of the Humboldt, Benguela and Leeuwin Current systems. J R Soc West Aust 74:59-69

Nelson WA (1999) A revised checklist of marine algae naturalised in New Zealand. NZ J Bot 37:355-359

Ngan Y, Price IR (1979) The intertidal algae of the mainland coast in the vicinity of Townsville, Queensland. Atoll Res Bull 237:1-29

Ngan Y, Price IR (1980a) Seasonal growth and reproduction of intertidal algae in the Townsville region (Queensland, Australia). Aquat Bot 9:117-134

Ngan Y, Price IR (1980b) Distribution of intertidal benthic algae in the vicinity of Townsville, tropical Australia. Aust J Mar Freshw Res 31:175-191

Olsen JL, Valero M, Meusnier I, Boele-Bos S, Stam W (1998) Mediterranean Caulerpa taxifolia and C. mexicana (Chlorophyta) are not conspecific. J Phycol 34:850-856

Olsen JL, Valero M, Meusnier I, Boele-Bos S, Stam W (1999) Reply to comment by Chisholm and Jaubert. J Phycol 35:441

Pakker H, Breeman AM, Prud'homme van Reine WF, van den Hoek C (1995) A comparative study of temperature responses of Caribbean seaweeds from different biogeographic groups. J Phycol 31:499-507

Pakker H, Klerk H, Hein van Campen J, Olsen JL, Breeman AM (1996) Evolutionary and ecological differentiation in the pantropical to warm-temperate seaweed Digenea simplex (Rhodophyta). J Phycol 32:250-257

Phillips JA (1997) The Bacillariophyceae, Chlorophyceae, Chrysophyceae, Cyanophyceae, Euglenophyceae, Phaeophyceae, Rhodophyceae, Xanthophyceae. In: Henderson RJF (ed) Queensland plants: Names and distribution. Department of Environment, Brisbane, p 223-240

Pillen TL, Ringeltaube P, Dennison WC (1998) Are expanding populations of the tropical green alga Caulerpa taxifolia a potential threat for Moreton Bay? In: Tibbetts IR, Hall NJ, Dennison WC (eds) Moreton Bay and Catchment. School of Marine Science, University of Queensland, Brisbane, p 327-328

Pillmann A, Woolcott GW, Olsen JL, Stam WT, King RJ (1997) Inter- and intraspecific genetic variation in Caulerpa 
(Chlorophyta) based on nuclear rDNA ITS sequences. Eur J Phycol 32:379-386

Price IR, Larkum AWD, Bailey A (1976) Checklist of marine benthic plants collected in the Lizard Island area. Aust $\mathrm{J}$ Plant Physiol 3:3-8

Rayss T (1941) Sur les Caulerpes de la côte palestinienne. Palest J Bot 2:103-124

Ribera MA, Boudouresque CF (1995) Introduced marine plants, with special reference to macroalgae: mechanisms and impact. Prog Phycol Res 11:187-268

Saenger P (1979) Records of subtidal algae from the Swains Reef Complex, Great Barrier Reef, Queensland. Proc R Soc Queensl 90:51-55

Sant N, Delgado O, Rodriguez-Prieto C, Ballesteros E (1996) The spreading of the introduced seaweed Caulerpa taxifolia (Vahl) C. Agardh in the Mediterranean Sea: testing the boat transportation hypothesis. Bot Mar 39:427-430

Silva PC, Meñez EG, Moe RL (1987) Catalog of the benthic marine algae of the Philippines. Smiths Contrib Mar Sci 27:1-179

Silva PC, Basson P, Moe RL (1996) Catalogue of the benthic marine algae of the Indian Ocean. Univ Calif Publ Bot 79: 1-1279

Smith CM, Walters LJ (1999) Fragmentation as a strategy for Caulerpa species: fate of fragments and implications for management of an invasive weed. Mar Ecol 20:307-319

Sonder OW (1871) Die Algen des tropischen Australiens. Abh Verh Natwiss Ver Hambg 5:33-74

Sonder OW (1881) Supplementum ad volumen undecinum: algae Australianae hactenus cognitae. In: Mueller F (ed)

Editorial responsibility: Kenneth Heck (Contributing Editor), Dauphin Island, Alabama, USA
Fragmenta Phytographiae Australiae. Government Printer, Melbourne, p 1-42, 105-107

Sosa PA, Lindstrom SC (1999) Isozymes in macroalgae (seaweeds): genetic differentiation, genetic variability and applications in systematics. Eur J Phycol 34:427-442

Suhr JN (1834) Übersicht der Algen, welche von Hrn Ecklon an der südafrikanischen Küste gefunden worden sind. Flora (Jena) 1834:721-735

Taylor WR (1960) Marine algae of the eastern tropical and subtropical coasts of the Americas. University of Michigan Press, Ann Arbor

van den Hoek C (1987) The possible significance of longrange dispersal for the biogeography of seaweeds. Helgol Wiss Meeresunters 41:261-272

Weber-van Bosse A (1898) Monographie des Caulerpales. Ann Jard Bot Buitenzorg 15:243-401

Weber-van Bosse A (1913) Liste des algues du Siboga. I. Myxophyceae, Chlorophyceae, Phaeophyceae. SibogaExpeditie Monogr 59a, EJ Brill, Leiden

Womersley HBS (1984) The marine benthic flora of southern Australia Part I. South Australian Government Printing Division, Adelaide

Wynne MJ (1986) A checklist of benthic marine algae of the tropical and sub-tropical western Atlantic. Can J Bot 64: $2239-2281$

Wynne MJ (1998) A checklist of benthic marine algae of the tropical and sub-tropical western Atlantic: first revision. Beih Nova Hedwigia 116:1-115

Young PC, Kirkman H (1975) The seagrass communities of Moreton Bay, Queensland. Aquat Bot 1:191-202

Submitted: May 31, 2001; Accepted: April 4, 2002

Proofs received from author(s): July 15, 2002 